bioRxiv preprint doi: https://doi.org/10.1101/449850; this version posted November 30, 2020. The copyright holder for this preprint (which was not certified by peer review) is the author/funder, who has granted bioRxiv a license to display the preprint in perpetuity. It is made available under aCC-BY-NC-ND 4.0 International license.

\title{
Inactivation of the core cheVAWY chemotaxis genes disrupts chemotactic motility and organised biofilm formation in Campylobacter jejuni
}

Mark Reuter ${ }^{1}$, Eveline Ultee ${ }^{1}$, Yasmin Toseafa ${ }^{1}$, Andrew Tan ${ }^{1}$, and Arnoud H.M. van Vliet ${ }^{2, *}$

1. Gut Health and Food Safety Programme, Quadram Institute Bioscience, Norwich Research Park, Norwich, United Kingdom.

2. Department of Pathology and Infectious Diseases, School of Veterinary Medicine, Faculty of Health and Medical Sciences, University of Surrey, Guildford, United Kingdom

* Email: a.vanvliet@ surrey.ac.uk

Running title: Chemotaxis and biofilm formation in C. jejuni

Keywords: Campylobacter, chemotaxis, biofilm formation, flagellar motility

Total number of words in Abstract: 200

Total number of words in Manuscript text: 3285

Number of Figures: 5, Number of Tables: 1

Supplementary information: 2 Figures, 1 Movie (via Figshare), 2 Tables 
bioRxiv preprint doi: https://doi.org/10.1101/449850; this version posted November 30, 2020. The copyright holder for this preprint (which was not certified by peer review) is the author/funder, who has granted bioRxiv a license to display the preprint in perpetuity. It is made available under aCC-BY-NC-ND 4.0 International license.

Reuter et al

Chemotaxis and biofilm formation in $C$. jejuni

\section{ABSTRACT}

Flagellar motility plays a central role in the bacterial foodborne pathogen Campylobacter jejuni, as flagellar motility is required for reaching the intestinal epithelium and subsequent colonisation or disease. Flagellar proteins also contribute strongly to biofilm formation during transmission. Chemotaxis is the process directing flagellar motility in response to attractant and repellent stimuli, but its role in biofilm formation of $C$. jejuni is not well understood. Here we show that inactivation of the core chemotaxis genes cheVAWY in C. jejuni strain NCTC 11168 affects both chemotactic motility and biofilm formation. Inactivation of any of the core chemotaxis genes (cheA, cheY, cheV or cheW) impaired chemotactic motility but did not affect flagellar assembly or growth. The $\Delta c h e Y$ mutant swam in clockwise loops, while complementation restored normal motility. Inactivation of the core chemotaxis genes interfered with the ability to form a discrete biofilm at the air-media interface, and the $\Delta c h e Y$ mutant displayed reduced dispersal/shedding of bacteria into the planktonic fraction. This suggests that while the chemotaxis system is not required for biofilm formation per se, it is necessary for organized biofilm formation. Hence interference with the Campylobacter chemotaxis system at any level disrupts optimal chemotactic motility and transmission modes such as biofilm formation. 
bioRxiv preprint doi: https://doi.org/10.1101/449850; this version posted November 30, 2020. The copyright holder for this preprint (which was not certified by peer review) is the author/funder, who has granted bioRxiv a license to display the preprint in perpetuity. It is made available under aCC-BY-NC-ND 4.0 International license.

Reuter et al

Chemotaxis and biofilm formation in C. jejuni

\section{INTRODUCTION}

Campylobacter jejuni is an important causative agent of bacterial gastroenteritis in humans (Nichols et al, 2012), and is commonly transmitted via contaminated food, especially poultry meat (Tam et al, 2009). Infection with $C$. jejuni is also associated with neurodegenerative diseases like Miller-Fisher and Guillain-Barré syndrome (Poropatich et al, 2010). One of the key factors for $C$. jejuni is its flagella-based motility, as aflagellated $C$. jejuni are unable to cause disease in animal models, show strongly reduced host cell invasion in cell culture-based assays (Gao et al, 2014; Lertsethtakarn et al, 2011), are targeted by bacteriophages (Baldvinsson et al, 2014). and show reduced biofilm formation (Brown et al, 2014; Reuter et al, 2010; Svensson et al, 2014).

Biofilms are bacterial populations encased in an extracellular matrix, and the biofilm environment can support survival of the bacterial population in adverse environmental conditions, and assist in resistance to antimicrobials such as disinfectants and antibiotics (Costerton et al, 1999; Teh et al, 2014). C. jejuni can form a monospecies biofilm but can also integrate into biofilms already present (Hanning et al, 2008; Reeser et al, 2007; Teh et al, 2019; Teh et al, 2010). C. jejuni mutants with defects in biofilm formation show reduced chicken colonization, adhesion and invasion of epithelial cells, as well as reduced intracellular survival (Rahman et al, 2014; Svensson et al, 2009; Theoret et al, 2012). While flagella are not required for biofilm formation in $C$. jejuni, flagellated strains show higher levels of biofilm formation, and C. jejuni cells isolated from biofilms show higher levels of expression of flagellar proteins (Kalmokoff et al, 2006; Reuter et al, 2010; Svensson et al, 2014).

In bacteria, motility is commonly directed in response to attractant and repellant external and intracellular signals, with the core chemotaxis proteins CheA and CheY transmitting the signal to the flagellar switch to alter flagellar motor rotation (Korolik, 2018; Lertsethtakarn et al, 2011). The signals are sensed by methyl-accepting chemotaxis proteins (MCPs), and this sensing initiates a signalling cascade that results in autophosphorylation of the histidine kinase CheA. The 
bioRxiv preprint doi: https://doi.org/10.1101/449850; this version posted November 30, 2020. The copyright holder for this preprint (which was not certified by peer review) is the author/funder, who has granted bioRxiv a license to display the preprint in perpetuity. It is made available under aCC-BY-NC-ND 4.0 International license.

Reuter et al

Chemotaxis and biofilm formation in C. jejuni

phosphorylated CheA transfers the phosphate group to the response regulator CheY, with phosphorylated $\mathrm{CheY}$ interacting with the flagellar switch to alter flagellar motor rotation. $C$. jejuni contains a number of accessory proteins, such as the $\mathrm{CheW}$ and $\mathrm{CheV}$ proteins, a methyltransferase (CheR) and a methylesterase (CheB) (Korolik, 2018; Lertsethtakarn et al, 2011), as well as a large number of MCPs involved in sensing different stimuli relevant to transmission and infection, such as amino acids, deoxycholate, dicarboxylic acid TCA intermediates, fucose, and nutrients (Day et al, 2016; Dwivedi et al, 2016; Lubke et al, 2018; Reuter and van Vliet, 2013). Chemotaxisdefective mutants have been shown to be attenuated in disease models (Chandrashekhar et al, 2015; Hendrixson and DiRita, 2004; Yao et al, 1997), show reduced immunopathology (Bereswill et al, 2011) and chick colonization (Hendrixson and DiRita, 2004).

It was previously shown that fucose utilisation and chemotaxis are linked to biofilm formation (Dwivedi et al, 2016), and biofilm formation in C. jejuni is responsive to external stimuli such as oxygen availability (Reuter et al, 2010; Teh et al, 2017). In a recent study, biofilm formation as well as autoagglutination was shown to be increased in $C$. jejuni cheV and cheW mutants (Tram et $a l, 2020)$, and although these mutants were not complemented, it suggests a more direct link between chemotaxis and biofilm formation in Campylobacter. Here we have investigated the role of additional chemotaxis components in $C$. jejuni biofilm formation and chemotactic motility, by inactivation and complementation of the individual core chemotaxis genes cheVAWY in C. jejuni, and qualitative assessment of biofilm formation at air-liquid interfaces.

\section{MATERIALS AND METHODS}

\section{C. jejuni strains and growth conditions}

Campylobacter jejuni strain NCTC 11168 and its isogenic mutants (Table 1) were routinely cultured in a MACS-MG-1000 controlled atmosphere cabinet (Don Whitley Scientific) in 
bioRxiv preprint doi: https://doi.org/10.1101/449850; this version posted November 30, 2020. The copyright holder for this preprint (which was not certified by peer review) is the author/funder, who has granted bioRxiv a license to display the preprint in perpetuity. It is made available under aCC-BY-NC-ND 4.0 International license.

Reuter et al

Chemotaxis and biofilm formation in C. jejuni

microaerobic conditions $\left(85 \% \mathrm{~N}_{2}, 10 \% \mathrm{CO}_{2}, 5 \% \mathrm{O}_{2},\right)$ at $37^{\circ} \mathrm{C}$. For growth on plates, strains were either grown on Brucella agar or Blood Agar Base (BAB) with Skirrow supplement $\left(10 \mu \mathrm{g} \mathrm{ml}^{-1}\right.$ vancomycin, $5 \mu \mathrm{g} \mathrm{ml}^{-1}$ trimethoprim, $2.5 \mathrm{IU}$ polymyxin-B). Broth culture was carried out in Brucella broth (Becton Dickinson).

\section{Insertional inactivation and complementation of chemotaxis genes}

Insertional inactivation mutants were made as described previously (Reuter and van Vliet, 2013) using primers listed in Table S1, resulting in plasmids listed in Table S2. Plasmids were propagated in E. coli strain TOP10. To insert antibiotic resistance cassettes, BamHI sites were introduced in the target genes by inverse PCR (Table S1) and ligated to either the kanamycinresistance cassette ( $\Delta c h e Y, \Delta c h e W, \Delta c h e V$ mutants) or chloramphenicol-resistance cassette ( $\Delta c h e A$ mutant). All constructs were sequenced prior to transformation (Eurofins Genomics, Ebersberg, Germany). Single $C$. jejuni mutant strains (Table 1) were isolated after transformation of the $C$. jejuni NCTC 11168 wild-type strain with plasmids by electroporation (Reuter and van Vliet, 2013), followed by selection on plates supplemented with either $50 \mu \mathrm{g} \mathrm{ml}^{-1}$ kanamycin or $10 \mu \mathrm{g} \mathrm{ml} \mathrm{l}^{-1}$ chloramphenicol. To confirm the position of the antibiotic resistance cassette in antibiotic resistant clones, genomic DNA was isolated from four ml of overnight culture (DNeasy kit, QIAGEN). Diluted genomic DNA (50 ng) was used as template for PCR using primers that anneal outside of the cloned flanking regions in combination with antibiotic resistance cassette-specific primers (Table S1). C. jejuni mutants were complemented (Table 1) by inserting the individual chemotaxis genes (cheA, cheY, cheW, cheV) in trans using the cj0046 pseudogene, as described previously (Reuter and van Vliet, 2013). In these plasmids, the genes are expressed from the $f d x A$ promoter (van Vliet et al, 2001).

\section{Light microscopy and flagella staining using the Ryu stain}


bioRxiv preprint doi: https://doi.org/10.1101/449850; this version posted November 30, 2020. The copyright holder for this preprint (which was not certified by peer review) is the author/funder, who has granted bioRxiv a license to display the preprint in perpetuity. It is made available under aCC-BY-NC-ND 4.0 International license.

Reuter et al

Chemotaxis and biofilm formation in C. jejuni

Typically, $10 \mu \mathrm{l}$ of an overnight culture was examined using an Eclipse 50i microscope $(\times 100$ lens) to monitor swimming phenotypes. When necessary, a Coolpix 4500 digital camera (Nikon) was used to capture video (15 frames second ${ }^{-1}, 320 \times 240$ pixels). Video compilations were made by extracting appropriate frames using ImageJ (Rasband, W.S., ImageJ, U. S. National Institutes of Health, Bethesda, Maryland, USA, http://imagej.nih.gov/ij/, 1997-2014). To plot swimming behaviour, individual cells were tracked using the Manual tracking plug-in for ImageJ (Fabrice Cordeli, http://rsb.info.nih.gov/ij/plugins/track/track.html) then visualized using the Chemotaxis and Migration Tool (Ibidi, http://ibidi.com/software/chemotaxis_and_migration_tool/). To visualise flagella, cells were stained using the Ryu stain (Heimbrook et al, 1989) as described previously (Reuter et al, 2015). ImageJ was used to add a scale bar and prepare montage images.

\section{Chemotaxis assays}

Chemotactic motility was measured using soft agar motility assays and tube taxis assays (Reuter and van Vliet, 2013). All soft agar motility assays were carried out using Brucella soft agar in square $10 \mathrm{~mm}^{2}$ petri plates (Sterilin) inoculated with wild-type and three test strains, as described previously (Reuter and van Vliet, 2013). For each plate, halo size was expressed as a percentage of the corresponding wild-type and each strain was tested for significance using a one-sample t-test $($ alpha $=0.05)$, compared to a hypothetical value of $100($ GraphPad Prism 6.01). Strain-to-strain comparisons were made using a two-tailed Mann-Whitney test.

Tube taxis assays were prepared as described previously using Brucella soft agar (Reuter and van Vliet, 2013). The tubes were incubated at $37^{\circ} \mathrm{C}$ in air in a waterbath (Grant). Tubes were photographed after 24, 40, 48, 64, and 72 hours and the dye front was measured from the top of the agar using the ImageJ software and expressed as a percentage of the wild-type strain. Each strain was tested for significance using a one-sample t-test $($ alpha $=0.05)$ compared to a hypothetical value of 100 (GraphPad Prism 6.01) and strain-to-strain comparisons were made using a two-tailed 
bioRxiv preprint doi: https://doi.org/10.1101/449850; this version posted November 30, 2020. The copyright holder for this preprint (which was not certified by peer review) is the author/funder, who has granted bioRxiv a license to display the preprint in perpetuity. It is made available under aCC-BY-NC-ND 4.0 International license.

Reuter et al

Chemotaxis and biofilm formation in C. jejuni

Mann-Whitney test.

\section{Biofilm assays}

A $50 \mu \mathrm{l}$ single-use glycerol stock, routinely stored at $-80^{\circ} \mathrm{C}$, was used to inoculate a BAB plate with Skirrow supplements and these cells were used to inoculate fresh Brucella broth. Cultures were grown in microaerobic conditions with shaking overnight at $37^{\circ} \mathrm{C}$. The overnight culture was diluted to $\mathrm{A}_{600} \approx 0.05\left(\sim 1 \mathrm{x} 10^{7} \mathrm{CFU} \mathrm{ml}^{-1}\right)$ in $22 \mathrm{ml}$ sterile Brucella in a $50 \mathrm{ml}$ falcon tube. A twinfrost microscope slide (sterilized in $70 \%$ ethanol) was inserted into each falcon tube. Tubes were incubated at $37^{\circ} \mathrm{C}$ in microaerobic conditions without shaking. After 48 hours, slides were removed from the tubes using flamed-sterilized tweezers and briefly washed in water. Slides were dried in air before staining with $1 \%$ crystal violet. Unbound crystal violet was washed off with water and slides were dried in air. Biofilms were imaged using a GenePixPro microarray scanner (Axon). The photomultiplier tube (PMT) gain of either the $635 \mathrm{~nm}$ or $532 \mathrm{~nm}$ laser was adjusted to achieve a balanced image. To assess biofilm shedding, the $\mathrm{A}_{600}$ of the planktonic cultures were measured; statistically different results were determined using a two-tailed Mann-Whitney test (GraphPad Prism 6.01).

\section{RESULTS}

\section{Inactivation and complementation of the genes involved in the core chemotaxis system}

To assess the roles of the cheVAWY genes in $C$. jejuni chemotaxis, each individual gene was inactivated by a kanamycin or chloramphenical antibiotic resistance cassette in the same orientation as the gene (Table 1). To test for polar effects, each mutated gene was complemented by introduction of the different chemotaxis genes mutant in trans in the cj0046 pseudogene under control of the $f d x A$ promoter (Reuter and van Vliet, 2013). Inactivation of the chemotaxis genes did 
bioRxiv preprint doi: https://doi.org/10.1101/449850; this version posted November 30, 2020. The copyright holder for this preprint (which was not certified by peer review) is the author/funder, who has granted bioRxiv a license to display the preprint in perpetuity. It is made available under aCC-BY-NC-ND 4.0 International license.

Reuter et al

Chemotaxis and biofilm formation in C. jejuni

not result in significant changes in growth (Figure S1), and all isolates expressed flagella at both poles (Fig. 1). As the cheV, cheA and cheW genes are in an operon (Dugar et al, 2013; Porcelli et al, 2013), we confirmed that the downstream cheAW or cheW genes were still transcribed by reversetranscriptase PCR in the $\Delta c h e V$ and $\Delta c h e A$ mutants, respectively (not shown), although we cannot estimate changes in expression levels using this experimental approach. For all mutants and complemented strains described here, chemotactic motility was assessed using soft agar motility plates, and using tube taxis assays which measure motility in both an energy and redox gradient (Reuter and van Vliet, 2013).

\section{CheV is the dominant adaptor protein in the chemotaxis signalling pathway}

In liquid media, motility of the $\Delta c h e W$ and $\Delta c h e V$ mutants was comparable to the wild-type, but both halo formation and migration were reduced compared to the wild-type (Figures 2 and 3 ). Chemotactic motility of the $\Delta c h e W$ mutant was reduced to less than $50 \%$ compared to the wild-type strain at both 24 and 48 hours, respectively. The $\Delta c h e V$ mutant showed greater reduction in halo formation and migration in soft agar than the $\Delta c h e W$ mutant, when compared to the wild-type strain at both 24 and 48 hours. Complementation of the $\Delta c h e W$ mutant restored chemotaxis phenotypes to that of the wild-type strain. However, complementation of the $\Delta c h e V$ mutant did not restore chemotactic motility.

\section{Inactivation of the core chemotaxis genes $c h e Y$ and $c h e A$ disrupts chemotactic motility}

The $\Delta c h e Y$ mutant displayed the previously described chemotaxis defect (Yao et al, 1997), with chemotactic motility reduced to less than $20 \%$ of wild-type (Figures 2 and 3). Chemotactic motility was restored to wild-type levels by complementation with the cheY gene, and even exceeded that observed in the wild-type strain. The $\Delta c h e Y$ mutant showed a swimming behaviour reminiscent to the 'catherine wheel' firework (Lauga et al, 2006) in liquid media, where a cell would appear to get 
bioRxiv preprint doi: https://doi.org/10.1101/449850; this version posted November 30, 2020. The copyright holder for this preprint (which was not certified by peer review) is the author/funder, who has granted bioRxiv a license to display the preprint in perpetuity. It is made available under aCC-BY-NC-ND 4.0 International license.

Reuter et al

Chemotaxis and biofilm formation in C. jejuni

trapped in a clockwise swimming loop (see Supplementary Movie 1 and Fig. 4B) before resuming a darting motility as observed in the wild-type (Fig. 4A), while complementation of the $\Delta$ cheY mutant restored wild-type swimming behaviour (Fig. 4C). Inactivation of the cheA gene strongly reduced chemotactic motility, but introduction of the cheA gene in trans did not complement the $\Delta c h e A$ mutant (Figures 2 and 3), suggesting that other factors such as expression levels and stoichometry may be important in CheA function.

\section{Chemotaxis is required for organized biofilm formation at the air-media interface}

We investigated the role of chemotaxis in biofilm formation, by developing a glass slide-based assay combined with crystal violet staining, with detection using a microarray scanner (employing both lasers at 532 and $635 \mathrm{~nm}$ ). The wild-type strain formed a biofilm on the glass slide at the airmedia interface (Fig. 5). Below the air-media interface, a less-intense $\sim 2 \mathrm{~mm}$ band of adhered cells was observed. All of the chemotaxis mutants used in this study were defective in formation of a biofilm at the air-media interface (Fig. 5). In the $\Delta c h e W$ mutant, the air-media interface biofilm was present, but a second more intense area of adhered cells was also visible $\sim 5 \mathrm{~mm}$ below the airmedia interface. Both the $\Delta c h e V$ mutant and the complemented $\Delta c h e V$ mutant showed defective airmedia interface biofilm. The $\Delta c h e A$ and $\Delta c h e Y$ mutants both showed a disorganized air-media interface biofilm with a greater population of submerged cells. In all cases, except for the cheV and in part the cheA mutant, complementation with the respective wild-type gene restored the organised interface biofilm phenotype (Fig. 5). To assess the level of shedding of cells from the biofilm, the $\mathrm{A}_{600}$ of planktonic fraction for each assay was recorded. Inactivation of che $Y$ resulted in fewer cells in the planktonic fraction compared to the wild-type strain, while the complemented $\Delta c h e Y$ mutant had more cells in the planktonic fraction (Fig. S2). Therefore, the biofilm phenotype of at least the $\Delta c h e Y$ mutant could in part be due to a disruption of normal cell shedding/dispersal from the biofilm. To test the hypothesis that $C$. jejuni may require the fully functional chemotactic motility to 
bioRxiv preprint doi: https://doi.org/10.1101/449850; this version posted November 30, 2020. The copyright holder for this preprint (which was not certified by peer review) is the author/funder, who has granted bioRxiv a license to display the preprint in perpetuity. It is made available under aCC-BY-NC-ND 4.0 International license.

Reuter et al

Chemotaxis and biofilm formation in C. jejuni

seek the optimal environment for growth as a biofilm, the slide biofilm assay was performed using a paralysed flagella $(\triangle p f l A)$ mutant, which expresses flagella but is non-motile (Reuter et al, 2015; Yao et al, 1994). This mutant displayed low levels of biofilm formation at the air-media interface (Fig. 5). Thus, while the chemotaxis system is not required for biofilm formation per se, it is necessary for organized biofilm formation at the air-media interface and may play a role in dispersal/shedding of cells from the biofilm.

\section{DISCUSSION}

Flagellar motility plays an important role in colonisation and virulence of many bacterial pathogens. While the ability to move to or from locations is an important contributor to the infection process, such movement needs to be directed, and is commonly based on detection of external (e.g. chemical gradient) and internal stimuli (e.g. metabolic state). These stimuli can be positive or negative, with examples of positive stimuli being attractants such as nutrients, while negative stimuli can be repellents such as bile acids. The chemotaxis system integrates the signals from external and internal sensors through a signal transduction cascade consisting of MCPs, CheW/CheV, CheA and CheY, while other factors such as CheB or CheR, may modulate and finetune the signal transduction cascade, with diverse combinations observed throughout the bacterial kingdom (Lertsethtakarn et al, 2011; Micali and Endres, 2016). In this study we have dissected the core chemotaxis signalling pathway of the important foodborne zoonotic pathogen $C$. jejuni, which is the most common bacterial cause of gastroenteritis in the developed world. Directed motility is central to the process of intestinal colonisation by $C$. jejuni, as mutants defective in motility or chemotaxis are either unable to colonise or show significantly reduced efficiency of colonisation (de Vries et al, 2017; Yao et al, 1997).

While the CheA and CheY proteins are universal to bacterial chemotaxis systems, and bacteria may have one or multiple copies of these proteins, there is considerable variation in the adapter 
bioRxiv preprint doi: https://doi.org/10.1101/449850; this version posted November 30, 2020. The copyright holder for this preprint (which was not certified by peer review) is the author/funder, who has granted bioRxiv a license to display the preprint in perpetuity. It is made available under aCC-BY-NC-ND 4.0 International license.

Reuter et al

Chemotaxis and biofilm formation in C. jejuni

proteins such as $\mathrm{CheV}$ and $\mathrm{CheW}$. Campylobacter is not exceptional in having both $\mathrm{CheV}$ and

CheW proteins. Although CheW is the most common chemotaxis 'adaptor' protein (found in nearly $100 \%$ of genomes containing the core chemotaxis components, CheV was found in almost $40 \%$ of chemotaxis-positive genomes (Wuichet and Zhulin, 2010). Only three genomes (B. thuringiensis, $B$. weihenstephanensis, and L. monocytogenes) were found to contain $\mathrm{CheV}$ orthologs without CheW orthologs, suggesting that $\mathrm{CheV}$ alone can function in the MCP-CheA complex (Wuichet and Zhulin, 2010). In $C$. jejuni, the chemotaxis phenotype of the $\Delta c h e W$ mutant is the least severe (Figures 2, 3 and 5), suggesting that $\mathrm{CheV}$ does function to elicit some signal transduction event. Similar effects were observed in B. subtilis (Rosario et al, 1994) and further showed that the CheW domain of $\mathrm{CheV}$ was sufficient for signal transduction. A direct protein-protein interaction between CheV and Tlp4 (deoxycholate sensor, Cj0262c), Tlp6 (TCA intermediates sensor, Cj0448c), and Tlp8 (redox sensor CetZ) has been documented (Parrish et al, 2007) and Yeast Two- and ThreeHybrid analysis and immunoprecipitation were used to show that Tlp1 interacts with both CheW and $\mathrm{CheV}$, although the interaction with $\mathrm{CheV}$ was much stronger and localised to the $\mathrm{CheV}-\mathrm{W}$ domain (Hartley-Tassell et al, 2010). Both $\Delta c h e V$ and $\Delta c h e W$ mutants had chemotactic motility defects in Brucella media although chemotaxis towards aspartate was still competent in either mutant (Hartley-Tassell et al, 2010). Similarly, the novel chemotaxis protein Cj0371 of $C$. jejuni was shown to interact with the CheV protein, and influence ATPase activity of CheA (Du et al, 2016), suggesting that multiple systems engage in the chemotaxis pathway to modulate signal transduction. An evolutionary genomics study showed that the presence of $\mathrm{CheV}$ is correlated with increased numbers of MCPs and proposed that $\mathrm{CheV}$ functions to accommodate signal transduction from a specific group of MCPs, exemplified by the Salmonella McpC chemoreceptor (Ortega and Zhulin, 2016). None of the ten C. jejuni MCPs share the architecture of the McpC-type sensor. Moreover, H. pylori genomes encode only four chemotaxis sensors and three CheV proteins (Jimenez-Pearson et al, 2005). The C-terminal receiver domain on $\mathrm{CheV}$ most likely refines the 
bioRxiv preprint doi: https://doi.org/10.1101/449850; this version posted November 30, 2020. The copyright holder for this preprint (which was not certified by peer review) is the author/funder, who has granted bioRxiv a license to display the preprint in perpetuity. It is made available under aCC-BY-NC-ND 4.0 International license.

Reuter et al

Chemotaxis and biofilm formation in C. jejuni

function of this protein. It has previously been proposed that CheV acts as a phosphate sink, normalizing over-stimulation of CheA (Karatan et al, 2001; Ortega and Zhulin, 2016; Pittman et al, 2001).

Previous studies have implicated chemotaxis sensors in biofilm formation. A mutant lacking Tlp3 (Cj1564) showed increased biofilm formation (Rahman et al, 2014), while cetZ (Tlp8) mutants showed decreased biofilm formation (Chandrashekhar et al, 2015). We show that removing each component of the chemotaxis pathway results in disruption of biofilm formation at a discrete airsurface interface, and that this phenotype can be rescued by complementation for most of the chemotaxis genes investigated here. In this study, biofilm formation was reduced at the air-media interface in the $\Delta c h e V$ and $\Delta c h e W$ mutants, while cheV and cheW mutants of $C$. jejuni have also been reported to have increased biofilm formation (Tram et al, 2020). While this may appear conflicting, there are considerable differences in experimental setup. The well-based biofilm assay may also measure agglutinated cells stuck to the bottom of the well, whereas the air-media interface assay used in our study only qualitatively investigates the cells at that interface, and does not include cells congegrating at the bottom of wells. Many assays used for measuring biofilm formation are relatively crude, need careful interpretation to avoid over-interpretation, and are difficult to directly compare. However, these minor differences do not alter the conclusion that the chemotaxis system likely has a role in coordinating biofilm formation in $C$. jejuni, and that this coordinating role may extend to shedding and dispersal of cells from the biofilm. This study is therefore the first to present a role for signal transduction in the active dispersal of cells from a $C$. jejuni biofilm. In food-processing environments, biofilms present a reservoir of cells that can subsequently re-contaminate the food chain highlighting the need to learn more about biofilm dispersal.

In conclusion, the ability to couple flagella rotation with environmental sensing is an effective adaptive mechanism allowing bacteria to seek an optimum environment. While chemotaxis systems 
bioRxiv preprint doi: https://doi.org/10.1101/449850; this version posted November 30, 2020. The copyright holder for this preprint (which was not certified by peer review) is the author/funder, who has granted bioRxiv a license to display the preprint in perpetuity. It is made available under aCC-BY-NC-ND 4.0 International license.

Reuter et al

Chemotaxis and biofilm formation in C. jejuni

from model organisms such as E. coli and B. subtilis provide an effective model for studying signal transduction in non-paradigm organisms, species-specific modulations and augmentations abound and require focussed investigation. Such genus- and species-specific analyses will be required to better understand chemotaxis in other Epsilon-proteobacteria and other organisms that share elements of the Campylobacter chemotaxis system and provides a further paradigm for chemotaxis signal transduction.

Acknowledgments. The authors wish to thank Dr Henri Tapp for assistance with statistical evaluations, and members of the former IFR Campylobacter research group for helpful discussions. We would also like to thank Rachael Stanley for electron microscopy and Maddy Houchen and Robert Hindmarsh for microbiology media support.

Funding statement. The authors gratefully acknowledge the support of the Biotechnology and Biological Sciences Research Council (BBSRC) via the Gut Health and Food Safety Institute Strategic Programme (BB/J004529/1). The funder had no role in study design, data collection and analysis, decision to publish, or preparation of the manuscript. The authors declare that no competing interests exist. 
bioRxiv preprint doi: https://doi.org/10.1101/449850; this version posted November 30, 2020. The copyright holder for this preprint (which was not certified by peer review) is the author/funder, who has granted bioRxiv a license to display the preprint in perpetuity. It is made available under aCC-BY-NC-ND 4.0 International license.

Reuter et al

Chemotaxis and biofilm formation in C. jejuni

\section{REFERENCES}

Baldvinsson SB, Sorensen MC, Vegge CS et al. Campylobacter jejuni motility is required for infection of the flagellotropic bacteriophage F341. Appl Environ Microbiol. 2014;80:7096106.

Bereswill S, Fischer A, Plickert R et al. Novel murine infection models provide deep insights into the "menage a trois" of Campylobacter jejuni, microbiota and host innate immunity. PLoS One. 2011;6:e20953.

Brown HL, Reuter M, Salt LJ et al. Chicken juice enhances surface attachment and biofilm formation of Campylobacter jejuni. Appl Environ Microbiol. 2014;80:7053-60.

Chandrashekhar K, Gangaiah D, Pina-Mimbela R et al. Transducer like proteins of Campylobacter jejuni 81-176: role in chemotaxis and colonization of the chicken gastrointestinal tract. Front Cell Infect Microbiol. 2015;5:46.

Costerton JW, Stewart PS, Greenberg EP. Bacterial biofilms: a common cause of persistent infections. Science. 1999;284:1318-22.

Day CJ, King RM, Shewell LK et al. A direct-sensing galactose chemoreceptor recently evolved in invasive strains of Campylobacter jejuni. Nat Commun. 2016;7:13206.

de Vries SP, Linn A, Macleod K et al. Analysis of Campylobacter jejuni infection in the gnotobiotic piglet and genome-wide identification of bacterial factors required for infection. Sci Rep. 2017;7:44283.

Du X, Wang N, Ren F et al. cj0371: A Novel Virulence-Associated Gene of Campylobacter jejuni. Front Microbiol. 2016;7:1094.

Dugar G, Herbig A, Forstner KU et al. High-resolution transcriptome maps reveal strain-specific regulatory features of multiple Campylobacter jejuni isolates. PLoS Genet. 2013;9:e1003495.

Dwivedi R, Nothaft $\mathrm{H}$, Garber $\mathrm{J}$ et al. L-fucose influences chemotaxis and biofilm formation in Campylobacter jejuni. Mol Microbiol. 2016;101:575-89.

Gao B, Lara-Tejero M, Lefebre $\mathrm{M}$ et al. Novel components of the flagellar system in epsilonproteobacteria. mBio. 2014;5:e01349-14.

Hanning I, Jarquin R, Slavik M. Campylobacter jejuni as a secondary colonizer of poultry biofilms. J Appl Microbiol. 2008;105:1199-208.

Hartley-Tassell LE, Shewell LK, Day CJ et al. Identification and characterization of the aspartate chemosensory receptor of Campylobacter jejuni. Mol Microbiol. 2010;75:710-30.

Heimbrook ME, Wang WL, Campbell G. Staining bacterial flagella easily. J Clin Microbiol. 1989;27:2612-5.

Hendrixson DR, DiRita VJ. Identification of Campylobacter jejuni genes involved in commensal colonization of the chick gastrointestinal tract. Mol Microbiol. 2004;52:471-84.

Jimenez-Pearson MA, Delany I, Scarlato V et al. Phosphate flow in the chemotactic response system of Helicobacter pylori. Microbiology. 2005;151:3299-311.

Kalmokoff M, Lanthier P, Tremblay TL et al. Proteomic analysis of Campylobacter jejuni 11168 biofilms reveals a role for the motility complex in biofilm formation. $J$ Bacteriol. 2006;188:4312-20.

Karatan E, Saulmon MM, Bunn MW et al. Phosphorylation of the response regulator CheV is required for adaptation to attractants during Bacillus subtilis chemotaxis. J Biol Chem. 2001;276:43618-26.

Korolik V. The role of chemotaxis during Campylobacter jejuni colonisation and pathogenesis. Curr Opin Microbiol. 2018;47:32-7.

Lauga E, DiLuzio WR, Whitesides GM et al. Swimming in circles: motion of bacteria near solid boundaries. Biophys J. 2006;90:400-12.

Lertsethtakarn P, Ottemann KM, Hendrixson DR. Motility and chemotaxis in Campylobacter and Helicobacter. Annu Rev Microbiol. 2011;65:389-410. 
bioRxiv preprint doi: https://doi.org/10.1101/449850; this version posted November 30, 2020. The copyright holder for this preprint (which was not certified by peer review) is the author/funder, who has granted bioRxiv a license to display the preprint in perpetuity. It is made available under aCC-BY-NC-ND 4.0 International license.

Reuter et al

Chemotaxis and biofilm formation in C. jejuni

Lubke AL, Minatelli S, Riedel T et al. The transducer-like protein Tlp12 of Campylobacter jejuni is involved in glutamate and pyruvate chemotaxis. BMC Microbiol. 2018;18:111.

Micali G, Endres RG. Bacterial chemotaxis: information processing, thermodynamics, and behavior. Curr Opin Microbiol. 2016;30:8-15.

Nichols GL, Richardson JF, Sheppard SK et al. Campylobacter epidemiology: a descriptive study reviewing 1 million cases in England and Wales between 1989 and 2011. BMJ Open. 2012;2:e01179.

Ortega DR, Zhulin IB. Evolutionary Genomics Suggests That CheV Is an Additional Adaptor for Accommodating Specific Chemoreceptors within the Chemotaxis Signaling Complex. PLoS Comput Biol. 2016;12:e1004723.

Parkhill J, Wren BW, Mungall K et al. The genome sequence of the food-borne pathogen Campylobacter jejuni reveals hypervariable sequences. Nature. 2000;403:665-8.

Parrish JR, Yu J, Liu G et al. A proteome-wide protein interaction map for Campylobacter jejuni. Genome Biol. 2007;8:R130.

Pittman MS, Goodwin M, Kelly DJ. Chemotaxis in the human gastric pathogen Helicobacter pylori: different roles for $\mathrm{CheW}$ and the three $\mathrm{CheV}$ paralogues, and evidence for $\mathrm{CheV} 2$ phosphorylation. Microbiology. 2001;147:2493-504.

Porcelli I, Reuter M, Pearson BM et al. Parallel evolution of genome structure and transcriptional landscape in the Epsilonproteobacteria. BMC Genomics. 2013;14:616.

Poropatich KO, Walker CL, Black RE. Quantifying the association between Campylobacter infection and Guillain-Barre syndrome: a systematic review. J Health Popul Nutr. 2010;28:545-52.

Rahman H, King RM, Shewell LK et al. Characterisation of a multi-ligand binding chemoreceptor CcmL (Tlp3) of Campylobacter jejuni. PLoS Pathog. 2014;10:e1003822.

Reeser RJ, Medler RT, Billington SJ et al. Characterization of Campylobacter jejuni biofilms under defined growth conditions. Appl Environ Microbiol. 2007;73:1908-13.

Reuter M, Mallett A, Pearson BM et al. Biofilm formation by Campylobacter jejuni is increased under aerobic conditions. Appl Environ Microbiol. 2010;76:2122-8.

Reuter M, Periago PM, Mulholland F et al. A PAS domain-containing regulator controls flagellaflagella interactions in Campylobacter jejuni. Front Microbiol. 2015;6:770.

Reuter M, van Vliet AHM. Signal balancing by the CetABC and CetZ chemoreceptors controls energy taxis in Campylobacter jejuni. PLoS One. 2013;8:e54390.

Rosario MM, Fredrick KL, Ordal GW et al. Chemotaxis in Bacillus subtilis requires either of two functionally redundant CheW homologs. J Bacteriol. 1994;176:2736-9.

Svensson SL, Davis LM, MacKichan JK et al. The CprS sensor kinase of the zoonotic pathogen Campylobacter jejuni influences biofilm formation and is required for optimal chick colonization. Mol Microbiol. 2009;71:253-72.

Svensson SL, Pryjma M, Gaynor EC. Flagella-mediated adhesion and extracellular DNA release contribute to biofilm formation and stress tolerance of Campylobacter jejuni. PLoS One. 2014;9:e106063.

Tam CC, Higgins CD, Neal KR et al. Chicken Consumption and Use of Acid-Suppressing Medications as Risk Factors for Campylobacter Enteritis, England. Emerg Infect Dis. 2009;15:1402-8.

Teh AHT, Lee SM, Dykes GA. Do Campylobacter jejuni Form Biofilms in Food-Related Environments? Appl Environ Microbiol. 2014;80:5154-60.

Teh AHT, Lee SM, Dykes GA. The influence of dissolved oxygen level and medium on biofilm formation by Campylobacter jejuni. Food Microbiol. 2017;61:120-5.

Teh AHT, Lee SM, Dykes GA. Association of some Campylobacter jejuni with Pseudomonas aeruginosa biofilms increases attachment under conditions mimicking those in the environment. PLoS One. 2019;14:e0215275. 
bioRxiv preprint doi: https://doi.org/10.1101/449850; this version posted November 30, 2020. The copyright holder for this preprint (which was not certified by peer review) is the author/funder, who has granted bioRxiv a license to display the preprint in perpetuity. It is made available under aCC-BY-NC-ND 4.0 International license.

Reuter et al

Chemotaxis and biofilm formation in C. jejuni

Teh KH, Flint S, French N. Biofilm formation by Campylobacter jejuni in controlled mixed-microbial populations. Int J Food Microbiol. 2010;143:118-24.

Theoret JR, Cooper KK, Zekarias B et al. The Campylobacter jejuni Dps homologue is important for in vitro biofilm formation and cecal colonization of poultry and may serve as a protective antigen for vaccination. Clin Vaccine Immunol. 2012;19:1426-31.

Tram G, Klare WP, Cain JA et al. Assigning a role for chemosensory signal transduction in Campylobacter jejuni biofilms using a combined omics approach. Sci Rep. 2020;10:6829.

van Vliet AHM, Baillon MLA, Penn CW et al. The iron-induced ferredoxin FdxA of Campylobacter jejuni is involved in aerotolerance. FEMS Microbiol Lett. 2001;196:189-93.

Wuichet K, Zhulin IB. Origins and Diversification of a Complex Signal Transduction System in Prokaryotes. Science Signaling. 2010;3:ra50-ra.

Yao R, Burr DH, Doig $\mathrm{P}$ et al. Isolation of motile and non-motile insertional mutants of Campylobacter jejuni: the role of motility in adherence and invasion of eukaryotic cells. Mol Microbiol. 1994;14:883-93.

Yao R, Burr DH, Guerry P. CheY-mediated modulation of Campylobacter jejuni virulence. Mol Microbiol. 1997;23:1021-31. 
bioRxiv preprint doi: https://doi.org/10.1101/449850; this version posted November 30, 2020. The copyright holder for this preprint (which was not certified by peer review) is the author/funder, who has granted bioRxiv a license to display the preprint in perpetuity. It is made available under aCC-BY-NC-ND 4.0 International license.

Reuter et al

Chemotaxis and biofilm formation in C. jejuni

Table 1. Campylobacter jejuni strains used in this study.

\begin{tabular}{|c|c|}
\hline Strain & Description $^{\text {a }}$ \\
\hline \multicolumn{2}{|l|}{ C. jejuni strains } \\
\hline NCTC 11168 & Wild-type C. jejuni (Parkhill et al, 2000) \\
\hline $11168 \Delta$ cheY & NCTC $11168 c j 1118 c:: k a n^{R}$ \\
\hline $11168 \Delta$ cheW & NCTC $11168 c j 0283 c:: k a n^{R}$ \\
\hline $11168 \Delta c h e A$ & NCTC $11168 c j 0284 c:: c a t^{R}$ \\
\hline $11168 \Delta$ cheV & NCTC $11168 c j 0285 c:: k a n^{R}$ \\
\hline $11168 \Delta$ che $Y+\operatorname{che} Y$ & NCTC $11168 c j 1118 c:: k a n^{R} c j 0046:: c j 1118 c^{\mathrm{fdxApr} *} c a t^{R}$ \\
\hline $11168 \Delta$ cheW + cheW & NCTC $11168 c j 0283 c:: k a n^{R} c j 0046:: c j 0283 c^{\mathrm{fdxApr} *} c a t^{R}$ \\
\hline $11168 \Delta$ cheA + cheA & NCTC $11168 c j 0284 c:: c a t^{R} c j 0046:: c j 0284 c^{\mathrm{fdxApr} *} k a n^{R}$ \\
\hline $11168 \Delta$ cheV + che $e^{*}$ & NCTC $11168 c j 0285 c:: k a n^{R} c j 0046:: c j 0285 c^{\mathrm{fdxApr} *} c a t^{R}$ \\
\hline $11168 \Delta p f l A$ & NCTC $11168 c j 1565 c:: k^{2} n^{R}$ (Reuter et al, 2015) \\
\hline
\end{tabular}

a. $\quad \mathrm{kan}^{R}$, kanamycin resistance cassette; $\mathrm{cat}^{R}$, chloramphenicol resistance cassette; * denotes complementation construct: ${ }^{\mathrm{fdxApr}}$, gene under control of the constitutive $f d x A$ promoter. 
bioRxiv preprint doi: https://doi.org/10.1101/449850; this version posted November 30, 2020. The copyright holder for this preprint (which was not certified by peer review) is the author/funder, who has granted bioRxiv a license to display the preprint in perpetuity. It is made available under aCC-BY-NC-ND 4.0 International license.

Reuter et al

Chemotaxis and biofilm formation in C. jejuni

Figure 1

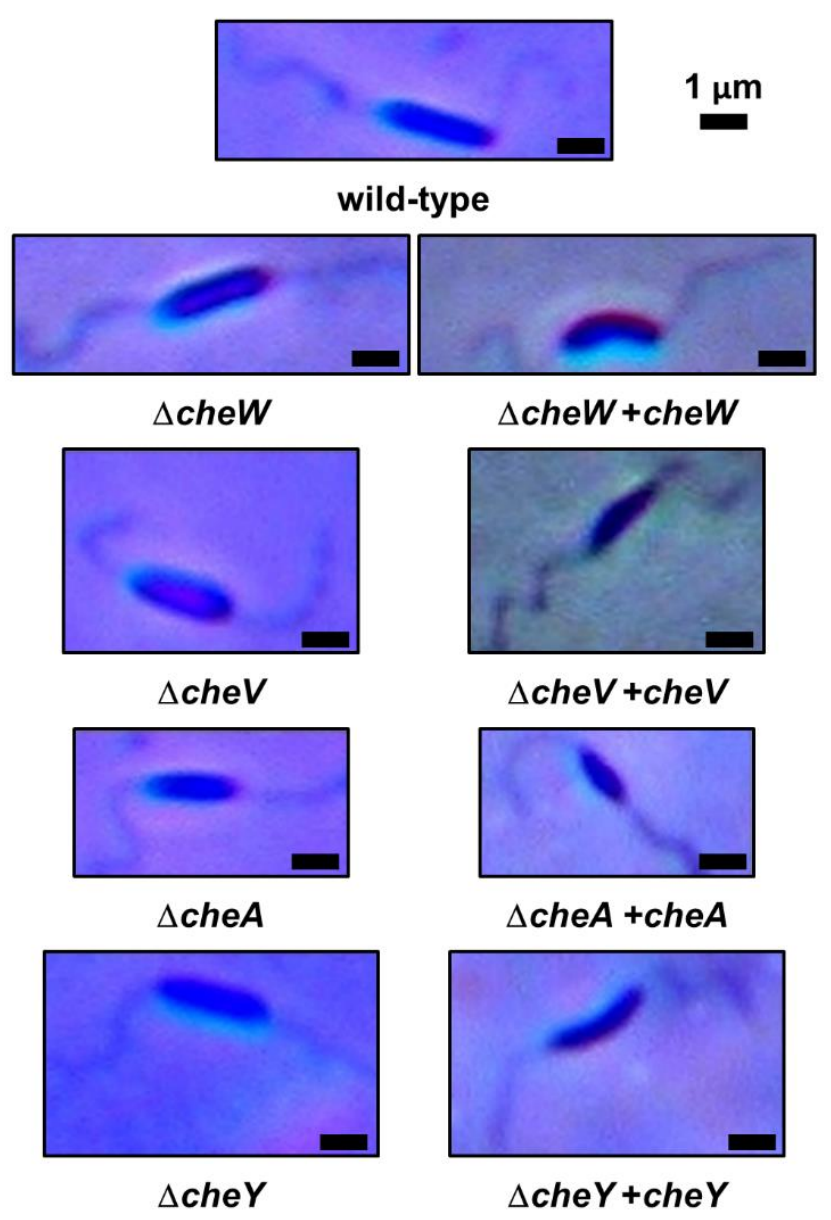

Figure 1. Disrupting chemotaxis proteins does not impair flagella assembly. Brucella broth cultures of wild-type $C$. jejuni NCTC11168 and the chemotaxis gene mutants and complemented strains were grown overnight at $37^{\circ} \mathrm{C}$ in microaerobic conditions. Cell were mounted between a microscope slide and coverslip and freshly prepared Ryu stain added adjacent to the coverslip. After five minutes, areas where the Ryu stain had penetrated were photographed at $\times 100$ magnification using a Nikon Coolpix 4500 digital camera. Montage images and scale bars were prepared using ImageJ. Scale bar $=1$ micron. Pictures are representative examples of multiple cultures each examined. 
bioRxiv preprint doi: https://doi.org/10.1101/449850; this version posted November 30, 2020. The copyright holder for this preprint (which was not certified by peer review) is the author/funder, who has granted bioRxiv a license to display the preprint in perpetuity. It is made available under aCC-BY-NC-ND 4.0 International license.

Reuter et al

Chemotaxis and biofilm formation in C. jejuni

Figure 2

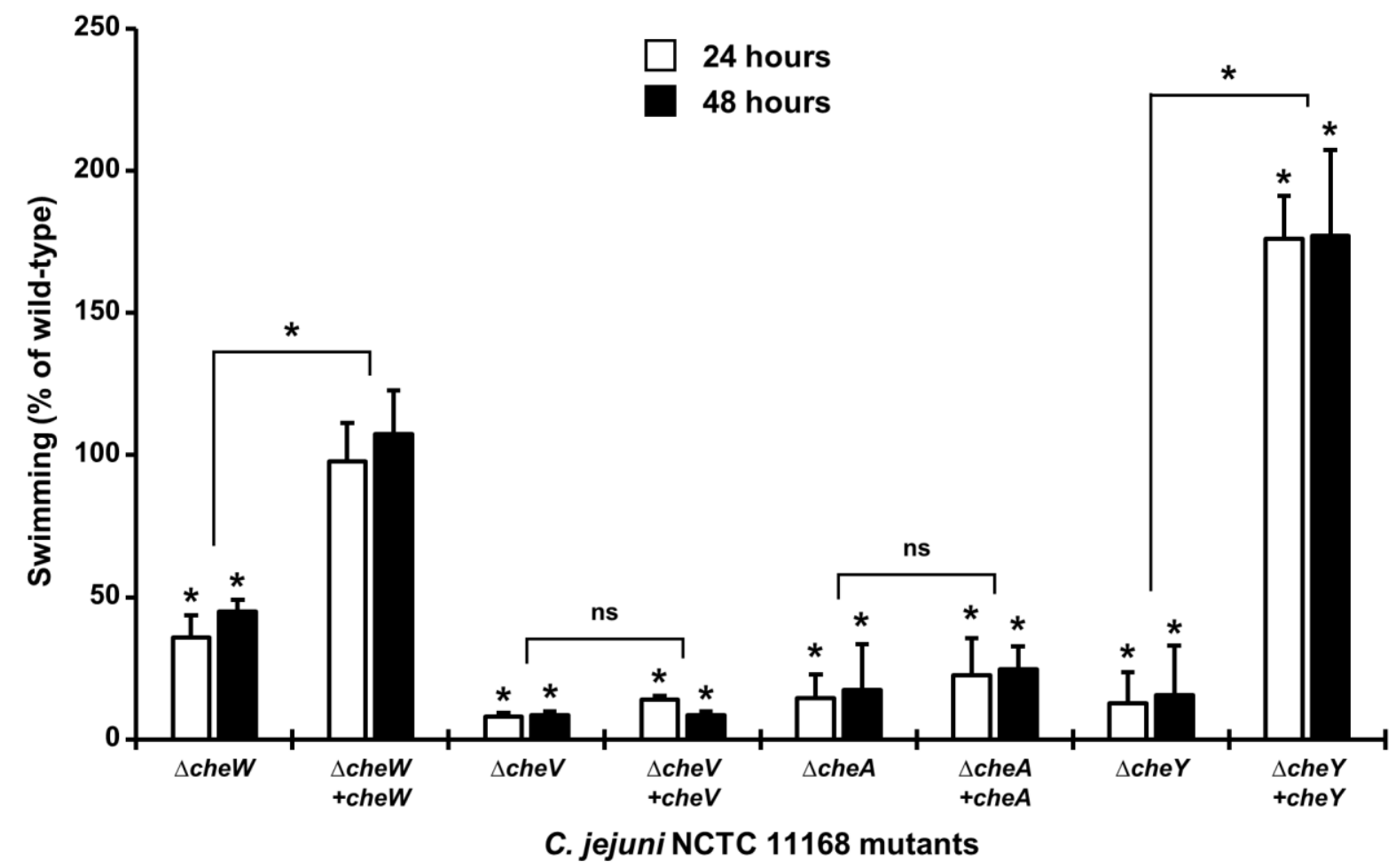

Figure 2. Chemotaxis mutants show a significant reduction in chemotactic motility in soft agar. For each chemotaxis mutant, the mutant strain was inoculated into $0.4 \%$ agar with the wild-type strain. Halo formation was measured after 24 and 48 hours and halo area expressed as the percentage of the halo for the wild-type strain. Raw mean area of WT was $293.2 \pm 15.52$ and $1230 \pm 63.69 \mathrm{~mm}^{2}$ ( 24 and $48 \mathrm{hrs}$ ). Results are the mean from at least three biological replicates and error bars show standard deviation. An asterisk denotes statistically significant results, based on a one-sample $t$-test (comparison with wild-type) or a two-tailed Mann-Whitney test $(\mathrm{p}<0.05)$. NS represents nonsignificant results. 
bioRxiv preprint doi: https://doi.org/10.1101/449850; this version posted November 30, 2020. The copyright holder for this preprint (which was not certified by peer review) is the author/funder, who has granted bioRxiv a license to display the preprint in perpetuity. It is made available under aCC-BY-NC-ND 4.0 International license.

Reuter et al

Chemotaxis and biofilm formation in C. jejuni

Figure 3

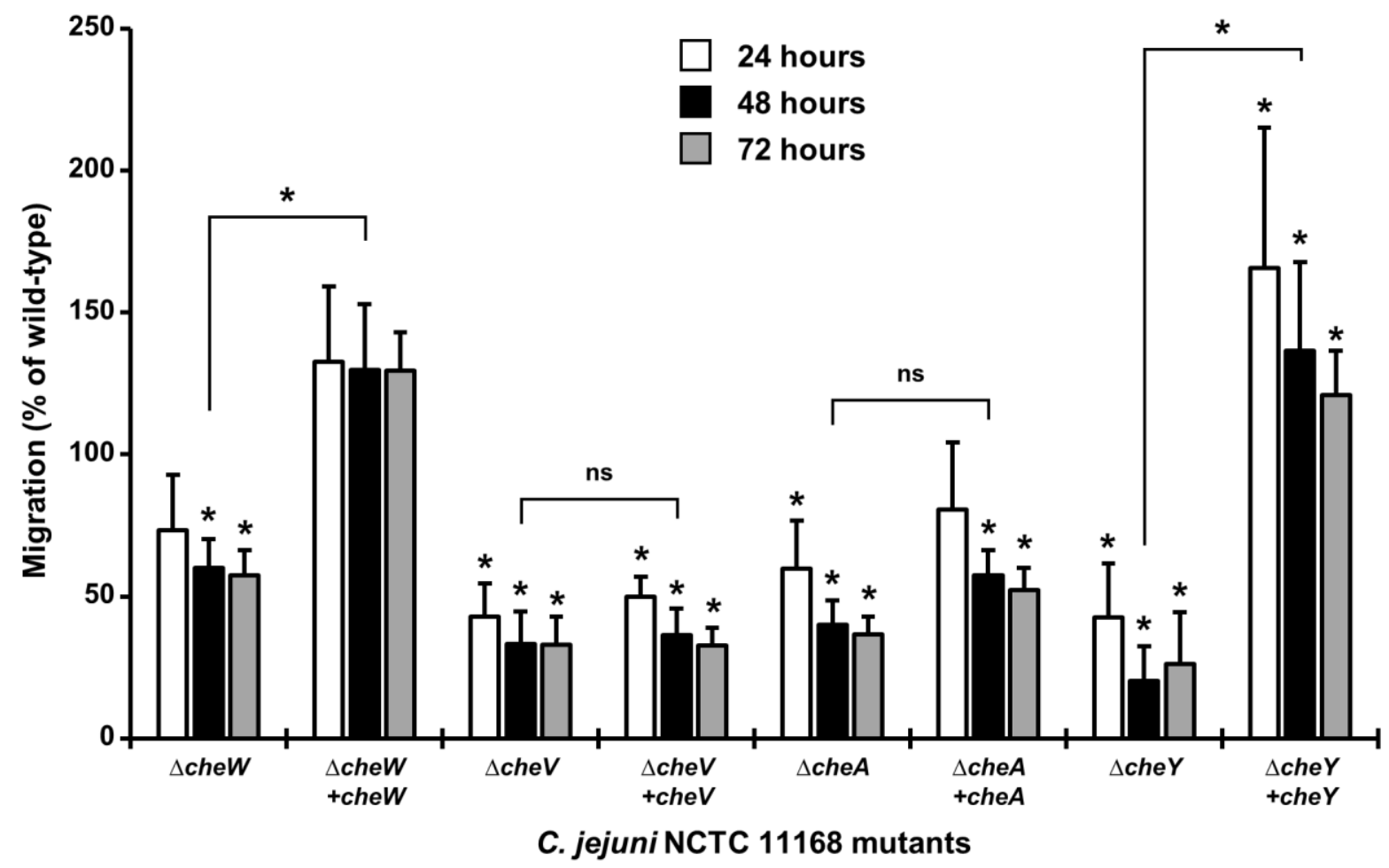

Figure 3. Chemotaxis mutants show a significant reduction in migration in an energy and redox gradient. Tube taxis assays for each strain were monitored over 72 hours at $37^{\circ} \mathrm{C}$ and the dye front measured after 24, 48 and 72 hours. Migration, calculated as a percentage of the wild-type used in the same assay, is shown at 24, 48, and $72 \mathrm{hrs}$ compared to WT (100\%) is shown. Raw mean migration for WT was $8.198 \pm 0.981,25.58 \pm 2.94$ and $48.03 \pm 5.09 \mathrm{~mm}$ for $24 \mathrm{~h}, 48 \mathrm{~h}$, and $72 \mathrm{~h}$, respectively. Results are the mean from at least four biological replicates and error bars show standard deviation. Asterisks denote statistically significant results, based on a one-sample $t$-test comparing mutant with wild-type $(\mathrm{p}<0.05)$. NS represents non-significant results. 
bioRxiv preprint doi: https://doi.org/10.1101/449850; this version posted November 30, 2020. The copyright holder for this preprint (which was not certified by peer review) is the author/funder, who has granted bioRxiv a license to display the preprint in perpetuity. It is made available under aCC-BY-NC-ND 4.0 International license.

Reuter et al

Chemotaxis and biofilm formation in C. jejuni

\section{Figure 4}
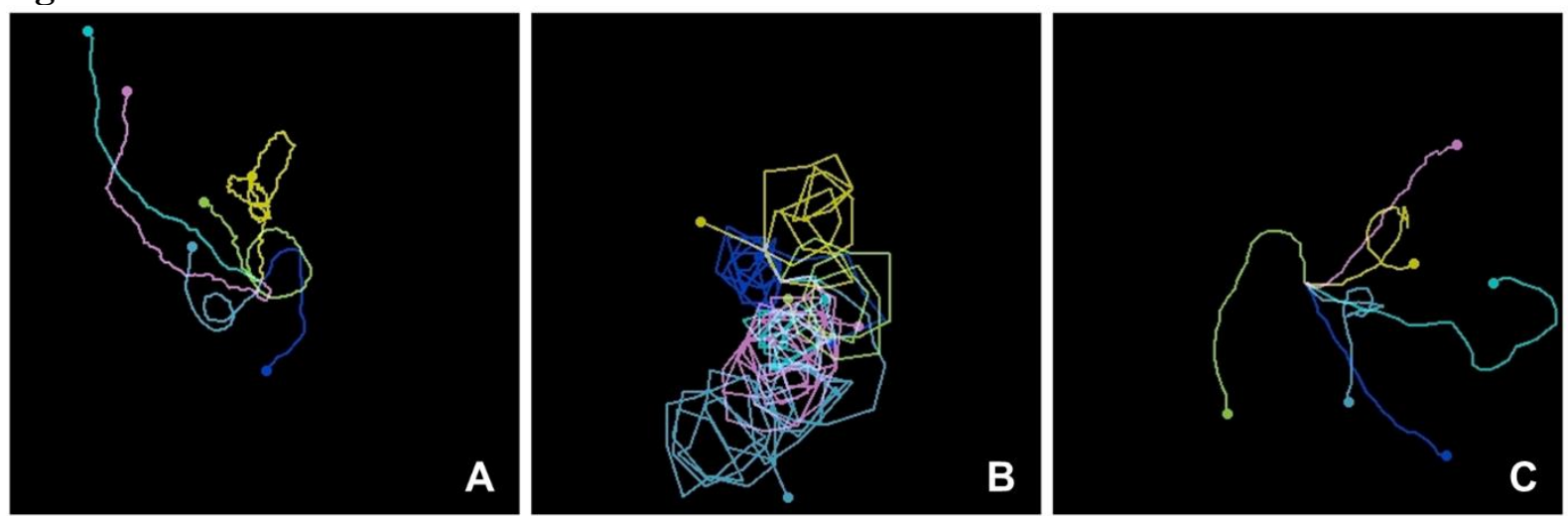

Figure 4. The $\Delta c h e Y$ mutant shows a swimming phenotype consisting of repeated clockwise swimming, similar to a 'catherine wheel' fireworks. Following $6-7$ hours growth at $37^{\circ} \mathrm{C}$ in microaerobic conditions, movies of swimming cells (A, wild-type; $\mathrm{B}, \Delta c h e Y$; $\mathrm{C}, \Delta c h e Y+c h e Y$; ) were recorded at $\times 100$ magnification using a light microscope and attached Nikon camera. Individual cells were tracked using the Manual Tracking ImageJ plug-in and swimming trajectories plotted using the Chemotaxis and Migration Tool (Ibidi). 
bioRxiv preprint doi: https://doi.org/10.1101/449850; this version posted November 30, 2020. The copyright holder for this preprint (which was not certified by peer review) is the author/funder, who has granted bioRxiv a license to display the preprint in perpetuity. It is made available under aCC-BY-NC-ND 4.0 International license.

Reuter et al

Chemotaxis and biofilm formation in $C$. jejuni

Figure 5
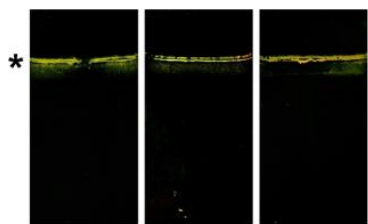

wild-type
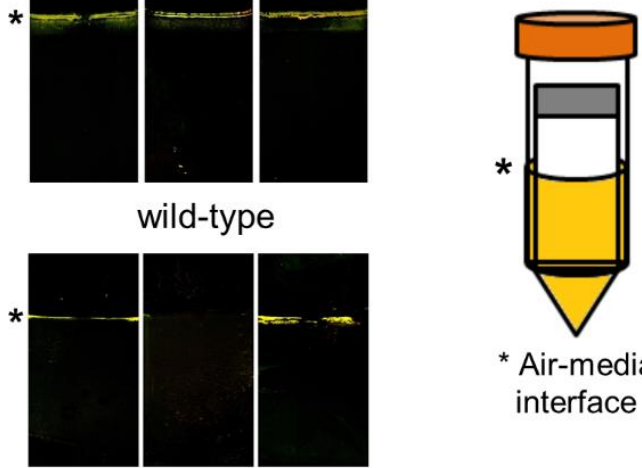

* Air-media

interface

$\Delta p f I A$
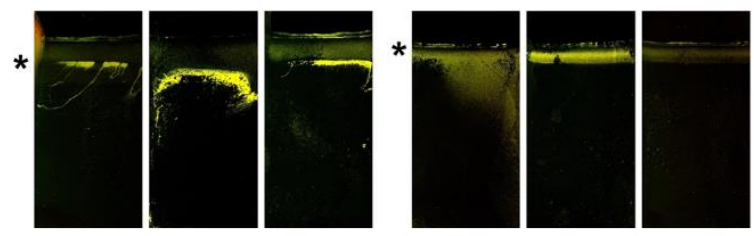

$\Delta$ cheW

$\Delta$ che $W+$ cheW
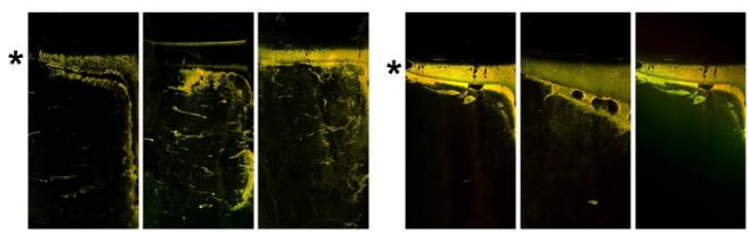

$\Delta$ cheV

$\Delta$ cheV +cheV
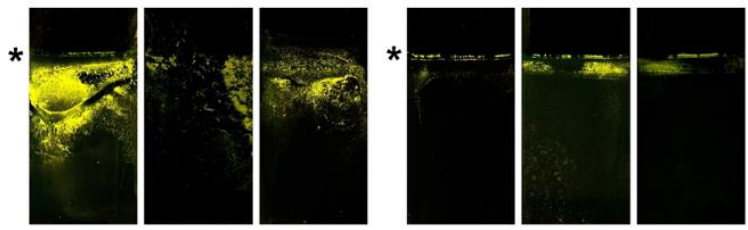

$\Delta$ cheA

$\Delta$ che $A+$ che $A$

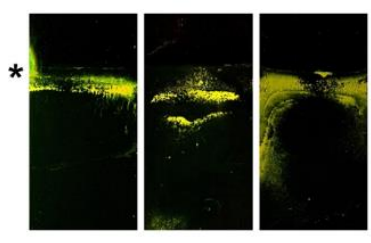

$\Delta$ cheY

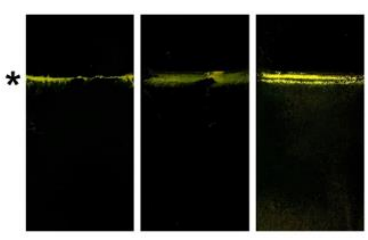

$\Delta$ che $Y+$ che $Y$

Figure 5. Chemotaxis is required for biofilm formation at the air-media interface. Static cultures of wild-type strain, chemotaxis mutants and complemented mutants were grown in the presence of a sterile glass slide, as shown in the cartoon on the top right $\left(37^{\circ} \mathrm{C}\right.$, microaerobic, $\left.48 \mathrm{hrs}\right)$. As a control, the paralyzed flagella strain $(\triangle p f l A)$ was included, which produces flagella but is nonmotile. Glass slides were removed and stained with $1 \%$ crystal violet $(\mathrm{CV})$. CV-stained biofilm was detected using a GenePix microarray scanner employing both 635 and $532 \mathrm{~nm}$ lasers. An asterisk shows the position of the air-media interface. Three independent biological repeats are shown for each strain. 